\title{
Engaging students in and with good academic work
}

\author{
David Baume \\ PhD SFSEDA FHEA
}

\begin{abstract}
It is proposed that efforts to enhance student engagement should focus attention on student engagement with good academic/professional/vocational work; hereafter, for simplicity, 'good work'. Three main reasons are advanced for this proposition. First: engaging with good work can provide a strong and clear motivation and goal for students who want to become competent or expert in a discipline, profession or vocation. 'Engaging with' here carries two hugely overlapping meanings; consuming (which includes, but is not limited to, reading, observing, critiquing, exploring, discussing and analyzing) and producing. Second: any programme, any module, any suggested student learning activity, any proposed teaching method, can be tested by answering the question 'Will it clearly and directly help the student to engage with, to consume and/or produce, good work?' And third: in engaging with good work, the student is always clear about the point and purpose of what they are doing - to identify the qualities of good work, to critique work against these qualities, and to produce good work.
\end{abstract}

Keywords: engagement; learning; course design; learning activities; learning outcomes; learning; skills.

\section{Introduction - learning and doing}

...not many years ago, I began to play the cello. I love the instrument, spend many hours a day playing at it, work hard at it, and mean someday to play it well. Most people would say that what I am doing is 'learning to play the cello'...But these words carry into our minds the strange idea that there exist two very different processes: (1) learning to play the cello; and (2) playing the cello. They imply that I will do the first until I have completed it, at which point I will stop the first process to 
begin the second...Of course this is nonsense. There are not two processes, but one. We learn to do something by doing it. There is no other way. (Holt, 1976, p.13)

John Holt was clearly strongly motivated - intrinsically motivated - to play the cello well. He describes how he also attended concerts and rehearsals, listened to recorded music, read and thought about music, especially the cello. He thereby built his own account of what it meant to play the cello well. He consumed as well as produced cello playing. And, when he wanted help, he took help in playing the cello better.

As well as having reservations about the concept of learning, and about the bad use educators sometimes make of the concept of learning, Holt also has reservations about the concept of skills. He dislikes the idea that we first learn skills and then apply these skills to action. He also dislikes the idea that we best learn big skills by breaking them into smaller skills and learning each smaller skill, and then somehow putting them together into the big skill (although he did practise his cello scales).

No, he says. We have a goal, however clearly or ill-formulated this goal is. Then, towards this goal, we act and obtain feedback (from ourselves and others), and then make sense of what we have done and of the feedback, and then do better. And we repeat this cycle throughout life, or until we are doing whatever we are doing as well as we want to do it, for now.

How does this relate to the design and operation of formal education?

\section{Some relevant numbers}

Gladwell (2008) (Chapter 2, the 10,000 hour rule) quotes several studies which suggest that becoming a world-class expert in any of a wide range of areas takes around 10,000 hours of work, of practice. More precisely; consider a group of people who start out with a similar (high) level of ability. What best differentiates those who achieve greatness from those who don't? Those who achieve greatness do far far more work than those who don't achieve greatness - around 10,000 hours as compared to perhaps 2,000 hours. What does this have to do with formal education? 
A UK honours degree, currently requiring three years of full-time study or its part-time equivalent, requires students to gain 360 credits. One credit notionally represents ten study hours (including both contact time and private study) (QAA, 2008). An honours degree thus notionally requires some 3600 study hours. If Gladwell's account has any validity, this means that students with good initial ability can get a third of their way to greatness by the end of their degree. Are most of your recent graduates a third of their way to greatness in their chosen field?

\section{Problems with this account}

Where may this analysis be wrong?

\section{Not all incoming students may have the high level of entry ability that the work reported by Gladwell describes.}

We do not know enough about whether the 10,000 hour rule applies to people of lesser initial ability. But it would be startling, counterintuitive, if the strong positive relationship between quantity of work and achievement did not at least in part hold for most or all people. Chickering and Gamson (1987) list 'time on task' as one of seven principles for good practice in undergraduate education, saying that students should spend the maximum possible time doing the subject; by contrast with, for example, being taught the subject.

\section{Students may not do the amount of work this model suggests.}

Bekhradnia (2009), based on responses from some 15,000 students in English Universities, suggests that students on average are studying for 29 hours each week, of which half is spent in class and half in private study (there are wide variations both within and across subjects). Brennan et al. (2009) show that this figure is the second lowest in Europe. Neither of these reports refers to the number of weeks in an academic year. However, assuming an academic year of 30 weeks, this suggests that UK students on average study for less than 900 hours per year rather than the notional 1200. 


\section{What are students doing with the hours they are spending?}

On Bekhradnia's account, each week students are spending some 14.5 hours in class and the same amount of time working outside class. But, again - what are they doing? We know very little about this. Handbooks typically refer to (depending on the discipline) lectures, seminars, tutorials, laboratory classes, studio sessions...These labels alone do not enable us to know what students will be doing, although we have some idea what they will be doing in laboratories and studios. 'Lecture' and 'seminar' can hide a multitude both of sins and virtues. Handbooks typically provide much less detail on what students are expected to do outside class beyond 'private study'. Where the hours associated with a module are specified, there will typically be good detail on how hours are allocated to lectures, seminars, etc. Private study time will often clearly be a residual, making up the total learning hours to, for example, 200 hours for a 20 credit module.

\section{Who decides how the student's time is spent?}

Holt describes playing the cello with the twin intentions of (a) enjoying making music and (b) playing the cello better and better. There is clearly a huge contrast between this and the typical experience of the student on a modular programme, who is shifting attention from subject to subject and topic to topic at the behest of the timetable, sometimes undertaking ill-defined private study, at other times undertaking assignments the point and purpose of which may or may not be clear. This is often a fragmented experience, mostly beyond the control of the student, not automatically conducive either to a high level of engagement or to a clear view of what is meant by good work.

\section{Designing and running courses to help students to do good work}

'Course' is used in this article to mean either programme (a whole degree) or module (a defined section of a programme, typically involving a small number of hundreds of hours of study). Where 'module' or 'programme' is specifically, meant, the appropriate word is used.

Imagine for a moment that the primary, perhaps even the sole, purposes of your course was to help students to engage with (produce and consume) good work. How might such a course look? How might such a course work? (Bates et al. (2010) develop a course design and resource allocation methodology using this idea). 
The course would surely require some sense of goal or purpose. Some students will bring to their studies a strong, even a passionate, goal. Hopefully they have chosen the right course. In this context, this means a course that will, if a student works hard and well, lead them to their goal. This requires much more than that the course is in the right subject, as this true story suggests:

Charles (not his real name) had been fascinated, from a very early age, by the sea. So he decided to study oceanography. He was accepted onto an oceanography degree. He left the course midway through the second year. Why? Charles said:

'They told us that oceanography uses a lot of physics, chemistry, biology. So, before we could do oceanography, we had to study physics, chemistry and biology. But, they told us, physics especially needs a lot of maths. So, before the physics, we needed to study maths. We weren't going to get to do any oceanography until the third year. So I left.'

There may have been some subject-based logic to this course design. But it ignored something vital: Charles' motivation for taking the oceanography degree - his fascination with the sea. (Adapted from Baume, 2009a)

Accepting that oceanography involves lots of science and mathematics, how could a degree programme in oceanography have worked better for Charles?

At a minimum, he and his fellow students could, in the first week of their studies, have been taken to sea, where they could have collected samples, made measurements, done small oceanographic projects, perhaps talked with or even supported experienced oceanographers, failing which, second or third year or doctoral students.

Back (mostly) on land, there could have been an oceanography module in every semester of the programme. Such a module would have enabled Charles and his fellow students to continue to engage with oceanography. Charles probably wasn't the only student who chose oceanography because of a passionate interest in the sea. But this programme-long succession of oceanography modules, carefully designed, could have enabled the students to pull together and integrate the necessary specialised studies of physics, chemistry, biology and maths. The students would integrate these other subjects into steadily more sophisticated and detailed accounts of oceanography. These evolving 
accounts of oceanography would of course be informed by their critical study of previous published work in oceanography. (A constructive approach to learning, which clearly informs the approach to course design suggested here, does not involve students ignoring previous work by scholars in the discipline. But it does involve students being guided to identify the good and less good qualities of previous work, and thus to develop and use criteria for good work).

What more could have been done? These next suggestions may be more contentious.

Mathematics modules tend to be taught by mathematicians, biology modules by biologists, and so on. Mathematicians and biologists tend to have a clear view of what comprises their subject, of what is essential knowledge in their subject. Might it be possible for oceanographers to work with mathematicians to define a curriculum in mathematics for oceanography, and so on? In raising such a question we may collide with issues of professional/disciplinary identity, with notions of academic purity, also with academic politics.

Concentrating on playing the cello, and on playing it better and better, John Holt did not take separate classes in 'fingering' and 'instrument maintenance' and 'reading a score'. Of course he learned to do all of these things, and many others besides. He learned them mainly by doing them, informed by guidance and by feedback, when he needed to; for example when he was unable to play a particular passage, or when a string broke. It is hard to imagine an effective modular course on playing the cello.

Perhaps all of Charles' oceanography degree should simply have been called 'oceanography'. All of it could truly have been about oceanography. The maths and physics and biology could have been studied in the context of oceanography. These other subjects would of course still have been labelled 'maths' and 'physics' and 'biology'. There is no intention to conceal from students the fact that they are studying these subjects, or that each of these subjects has an independent, substantial and important existence. But, it is suggested, these subjects should be put in their proper place. In this case their proper place is in support of the study of oceanography.

These subjects could have been studied as and when the particular oceanographic project, problem or challenge in which Charles and his fellow students were currently 
engaged required them. Then, for three years, Charles and his fellow students could truly have been doing oceanography, and at the same time becoming good, and still enthusiastic, oceanographers.

In some ways, as Charles' story suggests, it is easy to make the case in an interdisciplinary programme for focusing on the work that students do. But the same approach can work in a single-discipline programme. The overall programme outcome will presumably be, however expressed, that the student can do the discipline; that is, can produce good work in the discipline and can both articulate and apply the qualities of good work in the discipline. Even single-discipline courses are often designed and taught in modular form. Defining, producing and consuming doing good work can unify the programme for the students.

\section{Working within a course}

Thus far it has been assumed that you are designing a complete programme, for example, a degree. If this is not so - if you are responsible for designing a module or part of a module, even if you are running rather than designing a module or part of a module - is there anything you can do?

You can still focus, not on content or on teaching, but on the work students will do. You can design and run, for example, your three week section of a module around an assignment. If the assignment is appropriately designed and run, students will learn the necessary content. How should such an assignment work?

It is useful to be clear what students need to be able to do by the end of your section of the module. In the sometimes unloved but nonetheless useful language of higher education, you and your students need to be clear about the intended learning outcome of this section of the module, within the module and then the whole programme. You and your students also need to be clear what this learning outcome means; that is, what kinds and examples of work show this outcome being achieved (the writing and use of intended learning outcomes is explored in some detail in Baume 2009b). 
The intended learning outcome for your section of the module, and hence for your assignment, is likely to describe a type of question or problem your students need to be able to answer or solve, or a type of task they need to be able to undertake successfully. The intended learning outcome should embody or be accompanied by an account of what it means to achieve that outcome to an appropriate standard. The statement of intended learning outcomes should both describe and illustrate good work in response to that question or problem or task. The intended learning outcome is also likely to address how students should use existing published knowledge to inform their approach to the assignment.

Planning and running this section of the module, then, means ensuring that students have the necessary stimuli, support, access to resources (including you and each other), feedback and whatever else they affordably need in order to do the good work, to achieve the outcome well. It also means providing a suggested structure or process for answering the question or problem - as much or as little structure or process as your students need. Hopefully they will need much less such structure from you in later years of their studies. Hopefully in later years of the course they will also be able to play a greater role first in selecting, then later in designing, the assignments to help them achieve the outcome. They will be much more likely to develop this greater independence when 'solving problems' or 'undertaking assignments' - and, later in the course, 'designing assignments' - are explicit intended outcomes of their studies, and when students are helped to develop these capabilities, to pay attention to how they plan and do and review their work as well as to the content of the assignment. Running this three-week section of the module round an assignment will involve some teaching, but teaching will not be at the heart of it. At the heart of it will be the work the students do.

\section{Working around a course}

Much support for learning development is provided from outside the course. How may those providing such support use this suggested concentration on engagement with activities? Obvious suggestions include helping students dig into and interrogate the assignments that the students are set, to see what is being required of them; helping students to focus on doing the assignments; and exploring with students how they can use the assignments to extend and to show their knowledge and their capabilities. 


\section{A caution and a conclusion}

The concept of student engagement is based on the constructivist assumption that learning is influenced by how an individual participates in educationally purposeful activities. Learning is seen as a 'joint proposition'...however, which also depends on institutions and staff providing students with the conditions, opportunities and expectations to become involved. However, individual learners are ultimately the agents in discussions of engagement. (Coates 2005, cited Trowler and Trowler, 2010, p.9)

As Coates may be suggesting here, activity cannot safely be equated with engagement. Nor can the production of work. A student may undertake an activity whilst engaging only superficially with the activity.

Coates speaks of 'educationally purposeful activities'. But whose purpose? Active engagement with good academic, professional and/or vocational work surely requires students to care about the work that they are doing - to want to do it - to feel frustrated when the work does not go well, and to feel proud and satisfied when, in their view and in the view of peers and tutors, it does go well. Active engagement also requires students to be able to articulate what 'good work' means, and in what ways a particular piece of work, whether of their own production or someone else's, is good, and how it could be better.

What are the conditions for active engagement with good academic work? They surely include:

- The student has, and has confidence in, a clear and explicit account of their own current goals and aspirations.

- The student feels that they can change these goals and aspirations as they learn.

- There is a good match between the students' goals and aspirations and the intended outcomes of their programme of study, whether as written or as negotiated, varied and adapted between the student and their tutor.

- Students may well have major academic or professional aspirations and goals that cannot be met by their programme of study. Students need to feel that can move 
towards any such aspirations and goals through extra-curricular activity and/or concurrent employment or voluntary work.

- Students feel supported, by peers and tutors and support staff, in consuming and producing good work.

\section{References}

Bates, I., Baume, D. and Assinder, S. (2010) 'Focusing on student learning to guide the use of staff time', Innovations in Education and Teaching International, 47(4), pp. 357-367.

Baume, D. (2009a) Course design for increased student satisfaction. Leeds: Leeds Metropolitan University. Available at: http://tinyurl.com/2d2b528 (Accessed: 23 February 2011).

Baume, D. (2009b) Writing and using good learning outcomes. Leeds: Leeds Metropolitan University. Available at: http://tinyurl.com/3a2whed (Accessed: 23 February 2011).

Bekhradnia, B. (2009) The academic experience of students in English universities - 2009 Report. Oxford: Higher Education Policy Institute. Available at: http://tinyurl.com/33asys2 (Accessed: 23 February 2011).

Brennan, J., Patel, K. and Tang, W. (2009) Diversity in the student learning experience and time devoted to study: a comparative analysis of the UK and European evidence. London: Centre for Higher Education Research and Information, The Open University.

Chickering, A.W. and Gamson, Z.F. (1987) 'Seven principles for good practice in undergraduate education', AAHE Bulletin. Washington DC. Available at http://tinyurl.com/3aj3g8g (Accessed: 23 February 2011).

Gladwell, M. (2008) Outliers - the story of success. London: Allen Lane.

Holt, J. (1976) Instead of education. Canada: Clarke, Irwin. 
QAA (2008) Higher education credit framework for England: guidance on academic credit arrangements in higher education in England. Cheltenham: QAA. Available at: http://tinyurl.com/2vwx4br (Accessed: 23 February 2011).

Trowler, P. and V. Trowler (2010) Student engagement evidence summary. Higher Education Academy. Available at: http://tiny.cc/ka4uz (Accessed: 23 February 2011).

\section{Author details}

David Baume PhD SFSEDA FHEA is an independent higher education researcher, evaluator, consultant, staff and educational developer and writer. He was founding chair of the Staff and Educational Development Association (SEDA); a founder of the Heads of Educational Development Group (HEDG); and founding editor of the International Journal for Academic Development (IJAD). David was previously a Director of the Centre for Higher Education Practice at the Open University. He has co-edited three books on staff and educational development, and published some 60 papers, articles and reports on higher education teaching, assessment, evaluation, course design, portfolios and personal development planning. E-mail: adbaume@aol.com. 